\title{
Auxiliary genetic analysis in a Chinese adolescent NPH family by single nucleotide polymorphism screening
}

\author{
CHUNRONG TANG ${ }^{1,2^{*}}$, DAOYUAN ZHOU ${ }^{1,3,4^{*}}$, RONGSHAO TAN ${ }^{1,4}$, XIAOSHI ZHONG ${ }^{1,3}$, \\ XIAO XIAO ${ }^{1,3}$, DANPING QIN ${ }^{1,3,4}$, YUN LIU ${ }^{1,3,4}$, JIANGUANG HU ${ }^{1,3,4}$ and YAN LIU ${ }^{1,3,4}$
}

\author{
${ }^{1}$ Department of Nephrology, The First Affiliated Hospital of Jinan University, Guangzhou, Guangdong 510632; \\ ${ }^{2}$ Department of Nephrology, The Affiliated Hospital of Youjiang Medical University for Nationalities, Baise, Guangxi 530000; \\ ${ }^{3}$ Department of Nephrology; ${ }^{4}$ Guangzhou Institute of Disease-Oriented Nutritional Research, Guangzhou Red Cross Hospital, \\ The Fourth Affiliated Hospital of Medical College of Jinan University, Guangzhou, Guangdong 510220, P.R. China
}

Received March 28, 2019; Accepted November 18, 2019

DOI: $10.3892 / \mathrm{mmr} .2020 .10917$

\begin{abstract}
Hereditary nephropathy is a progressive fatal renal disease caused by genetic changes. In this study, genetic screening was used to reveal mutations in a family in Southern China, in which there are two patients with confirmed hereditary nephropathy, who are alive at the time of publication. Imaging tests, including color Doppler ultrasonography and magnetic resonance imaging (MRI), as well as pathological examinations, including hematoxylin-eosin staining, electron microscopy and immunohistochemistry were performed. Target sequencing of nephrosis 2 (NPHS2), wilms tumor 1 (WT1), phospholipase C $\varepsilon 1$ (PLCE1), actinin $\alpha 4$ (ACTN4), angiotensin I converting enzyme $(A C E)$, uromodulin $(U M O D)$ and nephrocystin 1 (NPHPl) was also carried out. This study indicated that heterozygous genetic variants of NPHS2, WT1, ACTN4, PLCE1 and UMOD found in the patients were gene polymorphisms. A renal biopsy showed sclerosing glomerulonephritis, dilated tubules and lymphocyte/monocyte infiltration in the interstitium of the index patients. Genetic analysis showed vertical transmission of the disease-causing mutations, including a homozygous deletion in NPHP1 and a nonsense mutation in $A C E$ found via PCR-based single nucleotide polymorphism screening. Further network analysis
\end{abstract}

Correspondence to: Professor Yan Liu, Department of Nephrology, Guangzhou Red Cross Hospital, The Fourth Affiliated Hospital of Medical College of Jinan University, 396 Tong Fu Zhong Road, Guangzhou, Guangdong 510220, P.R. China

E-mail: rabbityan127@163.com

*Contributed equally

Abbreviations: FSGS, focal segmental glomerular sclerosis; NPH, nephronophthisis; SNP, single nucleotide polymorphism; MRI, magnetic resonance imaging; $\mathrm{LOH}$, loss of heterozygosity; MCKD, medullary cystic kidney disease

Key words: familial, adolescent, nephronophthisis, genetic screening, mutation, homozygous deletion identified direct and indirect co-location genes between NPHPI and ACE. To conclude, familial adolescent nephronophthisis was diagnosed in two index patients in this study. It is recommended that comprehensive gene mutation screening is used in the diagnosis of complex hereditary diseases.

\section{Introduction}

Hereditary nephropathy is a progressive fatal renal disease caused by genetic changes in the somatic or germ cells (1). The main types, as previously described, include: Glomerular diseases, such as focal segmental glomerular sclerosis (FSGS); renal cystic lesions, such as autosomal dominant polycystic kidney disease; and renal tubular diseases, such as nephronophthisis (NPH) (2). The proportion of nephropathy cases in China through 2003-2014 that were primary glomerulonephritis, secondary glomerulonephritis, tubulointerstitial disease or hereditary renal diseases was 67.1, 26.4, 2.9 and $2.5 \%$, respectively (3). FSGS represents $20 \%$ of all nephrotic syndrome cases in children and is one of the five most common pathological changes in China, especially in Southern China, with a detection rate of $5.6 \%(4,5)$. However, kidney tubular disease such as NPH is also commonly observed in juvenile and adolescent subjects (6). Due to the non-specific pathological changes mentioned above, focal glomerular segmental sclerosis alone cannot be used to confirm the true pathogenic mechanism of FSGS. Therefore, genetic screening is adopted for diagnostic testing, especially for diagnosing patients with a history of genetic disease.

Genetic analysis has become a more accurate diagnostic method due to advances in medical technology and updating of the human genetic variation database $(7,8)$. The single nucleotide polymorphism (SNP) technique for detecting single base pair changes plays a vital role in the diagnosis of a number of diseases, including kidney damage (9). One genetic mutation can lead to different phenotypic changes, while one phenotypic change could be induced by multiple gene mutations. High-throughput mutation analyses have found mutations in Wilms tumor 1 (WT1), actinin $\alpha 4$ (ACTN4), nephrocystin 1 (NPHP1), nephrosis 2 (NPHS2), phospholipase C $\varepsilon 1$ (PLCE1), angiotensin I converting enzyme (ACE) and multidrug resis- 
tance mutation 1 genes in patients with pathological changes in FSGS (2,10-12). Mutations in 15 genes, including nephrocystin 1-13, uromodulin $(U M O D)$, Abelson helper integration site 1, and coiled-coil and C2 domain containing 2A have been found in patients with NPH worldwide (13-15). New mutation sites in the NPH population have been found with familial aggregation characteristics $(13,16-19)$.

In the present study, a Chinese family with hereditary renal injury was screened, and SNPs of NPHS2, WT1, PLCE1, ACTN4, ACE, NPHPl and UMOD were sequenced to explore the main causes of kidney damage and determine the genetic mutations in this Chinese family with hereditary nephropathy. This study also aimed to confirm the importance of genetic screening in the diagnosis of complex hereditary diseases.

\section{Materials and methods}

Familial data and sample collection. A total of 10 subjects ( 7 male and 3 female) were enrolled at the Guangzhou Red Cross Hospital between October and December 2012, the mean age of all patients was $27.90 \pm 19.92$. The families of the affected patients were enrolled, and the families of non-affected siblings were also recruited for bias reduction. Full medical and family histories were collected for pedigree analysis. Blood and urine samples were collected from each patient. Routine and biochemical tests were performed. Levels of albumin, parathyroid hormone and inflammatory factors were determined. Color Doppler ultrasonography and magnetic resonance imaging (MRI) of the kidney were also performed. Percutaneous renal samples were collected guided by B-ultrasound after obtaining informed consent from all the participants or their guardians. Consent forms were signed by the patients or their guardians. This study was approved by the ethics committee of the Guangzhou Red Cross Hospital (permit no. 20121228) and adhered to the tenets of the Declaration of Helsinki and the Guidance on Sample Collection of Human Genetic Diseases given by the Ministry of Public Health of China [Health Science and Education Planning Memo (2003) no. 80].

Hematoxylin-eosin staining. Kidney biopsy samples were routinely fixed in $2 \%$ glutaraldehyde buffer for $2-4 \mathrm{~h}$ at room temperature, embedded in optimal cutting temperature compound (OCT) for $15 \mathrm{~min}$ and cut into $\sim 5 \mu \mathrm{m}$ thick sections. The sections were soak in hematoxylin for $7 \mathrm{~min}$ for nuclear dying, then washed 3 times, differentiated with $0.5 \%$ hydrochloric acid alcohol and washed once before being placed into $1 \%$ ammonia solution for several seconds, and finally stained with $1 \%$ eosin for about $3 \mathrm{~min}$, all at room temperature. Hematoxylin-eosin (HE) sections were observed under light microscopy at 200x magnification.

Transmission Electron microscopy. A sample $\left(1 \mathrm{~mm}^{3}\right)$ was cut from the cortical end of kidney tissue and placed in $2.5 \%$ glutaraldehyde buffer for $2-4 \mathrm{~h}$ at $4{ }^{\circ} \mathrm{C}$, rinsed with PBS, and then fixed in a $1 \%$ citrate fixative solution for $1-2 \mathrm{~h}$. Following dehydration for $15 \mathrm{~min}$ with a graded ethanol series $(50,70$, 80 and $90 \%$ ), the sections were finally dehydrated with $100 \%$ ethanol for $30 \mathrm{~min}$. The tissue was embedded with fresh EPON812 resin at gradient temperature $\left(35,45\right.$ and $\left.60^{\circ} \mathrm{C}\right)$, each for $12 \mathrm{~h}$. The tissue was cut into $50 \mathrm{~nm}$ sections and double stained with $2 \%$ uranyl acetate and $\mathrm{pH} 12$ lead citrate at room temperature. Nanoparticle morphological properties of these kidney samples were confirmed using a transmission electron microscope at 13,500x magnification (Thermo Fisher Scientific, Inc.).

Immunohistochemistry of UMOD. Kidney tissue was embedded with $50 \%$ OCT for $10 \mathrm{~h}$ at room temperature and cut into $\sim 5 \mu \mathrm{m}$ thick sections. The sections were fixed in $4 \%$ paraformaldehyde solution for $15 \mathrm{~min}$ at room temperature and washed 3 times with PBS before being incubated in $0.4 \%$ pepsin for $30 \mathrm{~min}$ at $37^{\circ} \mathrm{C}$ for antigen retrieval and then blocked in $3 \%$ BSA for $30 \mathrm{~min}$ at room temperature. Immunohistochemical analysis of $U M O D$ was performed using a mouse monoclonal antibody against human UMOD (1:300, cat. no. ab207170, Abcam) at $4^{\circ} \mathrm{C}$ overnight, goat anti-mouse $\mathrm{IgG}$ was used as secondary antibody (1:500, cat. no. Ab150113, Abcam) at $37^{\circ} \mathrm{C}$ for $0.5 \mathrm{~h}$. I-VIEW DAB Universal Kit (Ventana Medical Systems, Inc.) was used for color reaction, after the termination of color development, hematoxylin was used for nuclear counterstain and observations were made under light microscopy at 400x magnification.

Immunofluorescence detection. Kidney samples were sliced into $\sim 5 \mu \mathrm{m}$ sections and fixed with $4 \%$ acetone for 15 min and washed 3 times with PBS at room temperature. Fluorescein-labeled antibodies IgG (1:150, cat. no. A0423, Dako, Agilent Technologies, Inc.), IgA (1:150, cat. no. A0262, Dako, Agilent Technologies, Inc.), IgM (1:200, cat. no. A0425, Dako, Agilent Technologies, Inc.), C3 (1:100, cat. no. F0201, Dako, Agilent Technologies, Inc.), C1q (1:100, cat. no. F0254, Dako, Agilent) (Dako, Agilent Technologies, Inc.), podocalyxin (1:300, cat. no. 14-8883-80, Invitrogen, Thermo Fisher Scientific, Inc.), fabrillarin (Fib) (1:200, cat. no. PA5-29801, Invitrogen, Thermo Fisher Scientific, Inc.) were added, and incubation was performed for $30 \mathrm{~min}$ at $37^{\circ} \mathrm{C}$. The samples were finally sealed with glycerin and observed under a fluorescence microscope at 400x magnification.

Targeted sequencing. Genomic DNA of the patients was extracted from the peripheral blood samples as per the instruction manual of the TIANamp Genomic DNA kit (Tiangen Biotech Co., Ltd.). Targeted first-generation sequencing of NPHS2, WT1, PLCE1, ACTN4, ACE and UMOD was performed in all family members except P7 who had died. Targeted second-generation sequencing of NPHPl was performed in P4, P5, P17, P18, P19, P20 and P21. Primers (presented in Tables SI-SVII) were designed and synthesized by Primer Premier 5 (Premier Biosoft International). These genes were sequenced on the Applied Biosystems 3730 DNA Analyzer (Applied Biosystems; Thermo Fisher Scientific, Inc.).

Total RNA was extracted from the peripheral blood samples using TRIzol (Invitrogen; Thermo Fisher Scientific, Inc.) according to the manufacturer's protocol. Total RNAs were reverse transcribed to cDNA using a FastKing RT kit (Tiangen Biotech Co., Ltd.) in a $10 \mu \mathrm{l}$ system with $2.5 \mu \mathrm{l}$ RNA sample, 10X King RT Buffer, $1 \mu 1$ FastKing RT Enzyme Mix, $2 \mu \mathrm{l}$ FQ-RT Primer Mix and 2.5 $\mu 1 \mathrm{RNase}-$ Free $\mathrm{ddH}_{2} \mathrm{O}$ at $42^{\circ} \mathrm{C}$ 


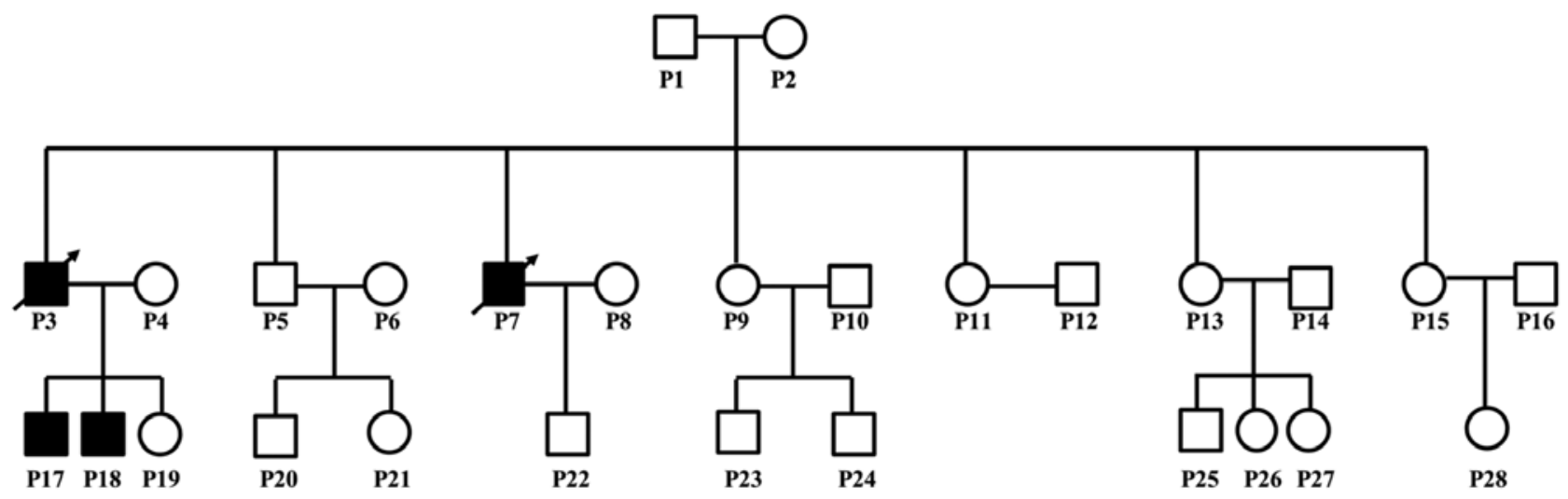

$\square$ Normal man $\bigcirc$ Normal female $\square$ Dale patients

Figure 1. Pedigree of the family. A total of 28 members were included in the family pedigree drawing. Four male patients were confirmed. Two family members in the second generation were dead (P3 and P7). Children of P3 were identified as having nephrotic disease (P17 and P18). Blank symbols denote healthy family members. Filled symbols denote affected family members. Filled symbols with black arrows denote dead, affected family members.

for $15 \mathrm{~min}$, then transferred to $95^{\circ} \mathrm{C}$ for $3 \mathrm{~min}$. The expression of NPHPl and mutated genes was verified using TaqMan ${ }^{\mathrm{TM}}$ quantitative (q)PCR analysis (Thermo Fisher Scientific, Inc.). PCR reaction conditions: DNA was pre-denatured at $95^{\circ} \mathrm{C}$ for $3 \mathrm{~min}$, cooled to $55-60^{\circ} \mathrm{C}$ for $35 \mathrm{sec}$, the primers were added, and then it was rapidly warmed to $72^{\circ} \mathrm{C}$ for 35 cycles. After Taq DNA polymerase was added, the primer strand was extended for 40-50 sec and put through repair extension at $72^{\circ} \mathrm{C}$ for $5-8 \mathrm{~min}$. The quantification method of qPCR experiments was $2^{-\Delta \Delta \mathrm{Cq}}(20)$. The relative expression levels of NPHP1 were normalized to those of GAPDH (F: CAAGGT CATCCATGACAACTTTG; R: GTCCACCACCCTGTT GCTGTAG).

Diagnostic criteria for familial adolescent NPH. Patients with a family history of NPH were presented. The main clinical characteristics of NPH include: Polyuria and polydipsia on account of renal concentration defection; growth retardation; anemia; and chronic renal failure. The renal pathological features of adolescent NPH include: Small to normal-sized kidneys; increased echogenicity and reduced corticomedullary differentiation; renal cysts on the corticomedullary border; and a dilated bladder.

Statistical analysis. The quantitative data were expressed as the mean \pm SD and the frequencies of qualitative data were described. Bioinformatics processing was performed following the sequencing procedure. The relationship between genes and diseases (polymorphism or causative) was evaluated with in combination with the Human Gene Mutation Database (http://www.hgmd.cf.ac.uk/ac/index. php) and Online Mendelian Inheritance in Man database (https://omim.org/) according to the ACMG guidelines (21). Mutated genes were evaluated using GeneMANIA v3.4.1 in Cytoscape v3.6.1 (https://cytoscape.org/) for gene co-location analysis (22). The GeneMANIA Cytoscape plugin was an efficient way of fast gene function prediction, including 6 categories: Co-expression, co-localization, genetic interaction, physical interaction, predicted and shared protein domain. Co-occurrence sequences are an important factor to related genome function, which can be determined by co-localization analysis. Colocalization analysis determines genomic co-localization characteristics and is used to assess nucleotide or spatial proximity of overlapping sequences between genes. The amount of overlaps or spatial proximity are two important evaluation indicators for gene co-localization analysis.

\section{Results}

Clinical and biochemical detection. P17 and P18 were the index patients; they were regarded as the starting point of this study. Disease history was recorded, and laboratory tests were performed for 10 family members across 3 generations (P1, P4, P5, P7, P17, P18, P19, P20, P21 and P22). Pedigree of the family showed that father P3 and uncle P7 of the two index patients were diagnosed with uremia and died at the age of 33 and 34 years, respectively. They were considered to be strong evidence of hereditary kidney disease, although specimens could not be obtained (Fig. 1).

The 10 enrolled patients included three females and seven males with a mean age of $27.8 \pm 19.97$ years and an average BMI of $17.71 \pm 3.0 \mathrm{~kg} / \mathrm{m}^{2}$. Three members had hyperuricemia without gout, and four members had hematuria. Connective tissue-associated nephropathy, HIV-related nephropathy, purpuric nephritis, hepatitis virus-associated nephritis, diabetic nephropathy, hypertensive renal damages and other related renal damages were excluded based on their clinical tests.

$\mathrm{P} 17$, a 20-year-old male had growth retardation, with a height of $162 \mathrm{~cm}$, weight of $38.5 \mathrm{~kg}$, and a low BMI of $14.7 \mathrm{~kg} / \mathrm{m}^{2}$. This patient was diagnosed with hereditary nephrosis at Guangzhou Red Cross Hospital. Serum testing showed an impaired glomerular filtration rate (urea, $26.5 \mathrm{mmol} / \mathrm{l}$; creatinine, $980 \mu \mathrm{mol} / \mathrm{l}$ ) and disturbed metabolism (parathyroid hormone, $165 \mathrm{pmol} / \mathrm{l}$ ).

P18, a 16-year-old male and the brother of P17, experienced growth retardation with a low BMI of $17.7 \mathrm{~kg} / \mathrm{m}^{2}$ (height of 
Table I. Clinical characteristics of the Chinese hereditary nephrotic family.

\begin{tabular}{|c|c|c|c|c|c|c|c|c|c|c|c|}
\hline \multirow[b]{2}{*}{ Characteristic } & \multicolumn{10}{|c|}{ Patient } & \multirow{2}{*}{$\begin{array}{l}\text { Reference } \\
\text { ranges }\end{array}$} \\
\hline & P17 & $\mathrm{P} 18$ & $\mathrm{P} 1$ & $\mathrm{P} 4$ & P5 & P7 & P19 & $\mathrm{P} 20$ & $\mathrm{P} 21$ & $\mathrm{P} 22$ & \\
\hline \multicolumn{12}{|l|}{ Demographic data } \\
\hline Sex & M & M & M & $\mathrm{F}$ & M & M & $\mathrm{F}$ & M & $\mathrm{F}$ & M & -- \\
\hline Age (years) & 20 & 16 & 73 & 44 & 33 & 40 & 18 & 14 & 12 & 9 & -- \\
\hline BMI $\left(\mathrm{kg} / \mathrm{m}^{2}\right)$ & 14.7 & 17.7 & 18 & 16 & - & 19 & 19 & 15 & 16 & 15 & $18.5-24.9$ \\
\hline $\begin{array}{l}\text { eGFR }(\mathrm{ml} / \mathrm{min} / \\
\left.1.73 \mathrm{~m}^{2}\right)\end{array}$ & 13.5 & 17.7 & 81.56 & 89.48 & 5.7 & 101.78 & 128.9 & 247.8 & 179.2 & 146.7 & \\
\hline \multicolumn{12}{|l|}{ Urine routine } \\
\hline Hematuria & Anuria & $\mathrm{T}$ & Mo & Mo & $\mathrm{T}$ & $\mathrm{T}$ & $\mathrm{N}$ & $\mathrm{N}$ & $\mathrm{N}$ & $\mathrm{T}$ & Negative \\
\hline White cell count $(/ \mu \mathrm{l})$ & 0 & 0 & 0 & 0 & - & 0 & 0 & 0 & 0 & 0 & $0.00 \sim 28.00$ \\
\hline Albumin (g/l) & $\mathrm{T}$ & 0.3 & $\mathrm{~N}$ & $\mathrm{~N}$ & - & $\mathrm{N}$ & $\mathrm{N}$ & $\mathrm{N}$ & $\mathrm{N}$ & $\mathrm{N}$ & Negative \\
\hline $\mathrm{pH}$ & 6 & 6 & 5.5 & 6.5 & 6.0 & 7 & 6.5 & 6.5 & 6 & 6 & $5.4 \sim 8.4$ \\
\hline Proportion & 1.01 & 1.02 & $\leq 1.005$ & 1.015 & 1.01 & 1.02 & $\leq 1.005$ & $\leq 1.005$ & 1.025 & 1.01 & $1.003 \sim 1.030$ \\
\hline \multicolumn{12}{|l|}{ Blood biochemical test } \\
\hline Urea (mol/l) & 13.8 & 17.6 & 6.8 & 5.4 & 26.5 & 6.5 & 4 & 5.2 & 4.8 & 4.7 & $1.9 \sim 6.8$ \\
\hline Creatinine $(\mu \mathrm{mol} / \mathrm{l})$ & 706 & 562 & 77 & 61 & 980 & 71 & 61 & 57 & 49 & 43 & $\begin{array}{l}\text { F: 53 9; } \\
\text { M: } 62 \sim 105\end{array}$ \\
\hline Uric acid $(\mu \mathrm{mol} / \mathrm{l})$ & 272.5 & 607.7 & 289 & 243.1 & 537 & 374.7 & 251.5 & 392 & 428.9 & 421.8 & $\begin{array}{l}\text { F: 155 357; } \\
\text { M: 208 428 }\end{array}$ \\
\hline Albumin (g/l) & 52.9 & 51.2 & 40.7 & 50.6 & 45 & 50.4 & 49.6 & 47.5 & 49.9 & 45.3 & $34 \sim 53$ \\
\hline Calcium (mmol/l) & 2.68 & 2.26 & 2.30 & 2.51 & - & 2.52 & 2.54 & 2.42 & 2.56 & 2.41 & $2.1 \sim 2.6$ \\
\hline Phosphorus (mmol/l) & 1.79 & 1.39 & 1.29 & 1.39 & - & 1.25 & 1.28 & 1.3 & 1.54 & 1.40 & $1.00 \sim 1.60$ \\
\hline $\begin{array}{l}\text { 25-hydroxyvitamin } \\
\text { D3 (ng/ml) }\end{array}$ & 59.6 & 47.2 & 33.1 & 37.4 & - & 38.3 & 28.4 & 29.9 & 25.3 & 15.1 & $30.1 \sim 100.0$ \\
\hline $\begin{array}{l}\text { Parathyroid hormone } \\
(\mathrm{pmol} / \mathrm{l})\end{array}$ & 17.65 & 16.66 & 3.41 & 4.02 & - & 2.23 & 3.1 & 3.09 & 3.34 & 5.06 & $1.6-6.9$ \\
\hline
\end{tabular}

Adjusted eGFR for Chinese population: C-aGFR $\left[\mathrm{ml} /\left(\mathrm{min} / 1.73 \mathrm{~m}^{2}\right)\right]=86 \mathrm{x} \mathrm{Scr}(\mathrm{mg} / \mathrm{dl})^{-1.154} \mathrm{x}$ age- $0.203 \mathrm{x} 1.233$ for male or 0.79 for female. $\mathrm{Scr}\left[\mathrm{ml} /\left(\mathrm{min} / 1.73 \mathrm{~m}^{2}\right)\right]=0.55 \mathrm{x}$ height $(\mathrm{m}) /$ blood creatinine $(\mathrm{mg} / \mathrm{dl})$. The reference value $\mathrm{Scr}$ for teenagers is 0.7 . BMI=weight $(\mathrm{kg}) /[\mathrm{height}$ $(\mathrm{m})]^{2}$. iPTH, immunoreactive parathyroid hormone; N, negative; $\mathrm{M}$, male; F, female; Mo, moderate; T, trace; eGFR, estimated glomerular filtration rate; C-aGFR, eGFR ( $\mathrm{ml} / \mathrm{min}$ per $\left.1.73 \mathrm{~m}^{2}\right)$ by modified abbreviated MDRD equation by adding a racial factor for Chinese; Scr, serum creatinine.

$160 \mathrm{~cm}$ and weight of $45.4 \mathrm{~kg}$ ) and was diagnosed with hereditary nephropathy at Guangzhou Red Cross Hospital. Laboratory testing showed slight gastrointestinal bleeding with weak positive hematuria, microalbuminuria, impaired glomerular filtration rate (urea, $28.9 \mathrm{mmol} / \mathrm{l}$; creatinine, $743 \mu \mathrm{mol} / \mathrm{l}$; calcium, $2.68 \mathrm{mmol} / \mathrm{l}$; phosphorus, $1.79 \mathrm{mmol} / \mathrm{l}$ ), and disordered metabolism (parathyroid hormone, $185 \mathrm{pmol} / \mathrm{l}$; Table I).

Imaging test. In P17, Color Doppler ultrasonography showed slightly narrowed, hyperechogenic kidneys $(62 \times 28$ and $54 \times 26 \mathrm{~mm}$, left and right kidneys, respectively) with decreased blood flow distribution and a blurred medullary boundary (Fig. 2A). Further analysis with MRI found a $0.8 \times 0.8 \mathrm{~cm}$ cyst near the medullary boundary (Fig. 2B). In P18, Color Doppler ultrasonography showed enlarged, hyperechogenic kidneys (100x49 and 100x49 mm, left and right kidneys, respectively) with an unclear medulla boundary; $5 \times 4 \mathrm{~mm}$-sized cysts were also observed (Fig. 2C). Further analysis with MRI found multiple small cysts in both of the kidneys (Fig. 2D).

Pathological examination. In P17, HE staining and electron microscopy revealed sclerosing glomerulonephritis, and increased lymphocyte and monocyte infiltration in the renal interstitium (Figs. 3A and 4A). Immunofluorescence staining revealed $\mathrm{IgG}, \operatorname{IgA}$ and $\operatorname{IgM}$ depositions in the mesangium matrix (Fig. 5A-C). In P18, HE staining and electron microscopy showed glomerular sclerosis, glomerular fibrosis crescents, tubular epithelial cell histiocytosis, and increased infiltration of lymphocytes and monocytes in the interstitium (Figs. 3B and 4B). Collagen fibers and monocytes infiltrations were also observed via electron microscopy (Fig. 4B). IgM and Fib depositions were observed in the mesangium matrix during immunofluorescence staining (Fig. 5D-F). Significantly dilated capillary loops, glomerular capsules and renal tubules were found. 

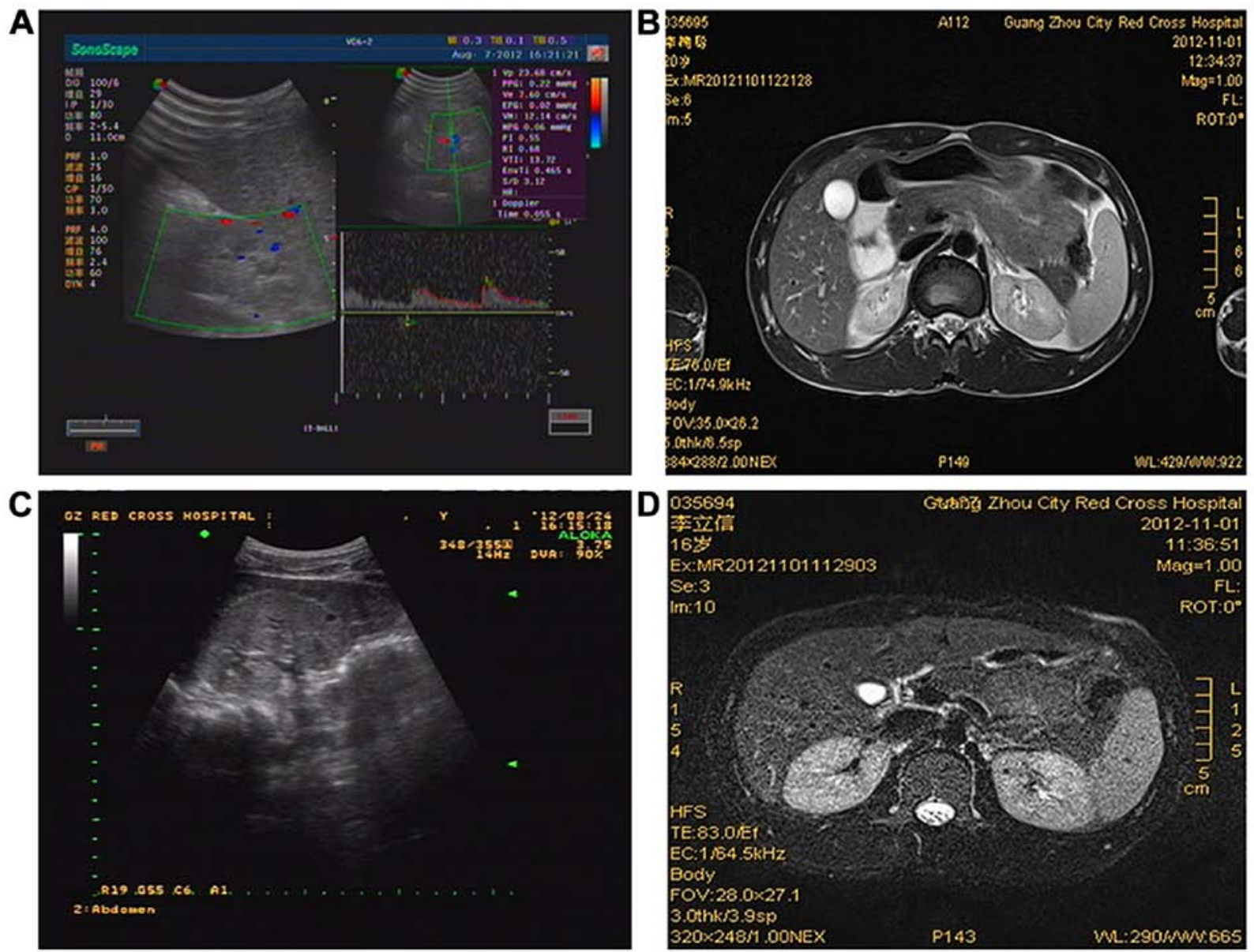

Figure 2. Color Doppler ultrasonography and MRI detections in index patients P17 and P18. (A) Color Doppler ultrasonography images of index patient P17. Two narrow kidneys with diffuse lesions reduced the blood flow distribution and increased resistance in the right kidney. (B) MRI image of index patient P17. Cyst with a size of $0.8 \times 0.8 \mathrm{~cm}$ near the medullary boundary was observed in the left kidney. (C) Color Doppler ultrasonography image of index patient P18 Slightly enlarged kidneys with an echo-free zone in the right kidney. (D) MRI image of index patient P18. Multiple small cysts were observed in both the kidneys. MRI, magnetic resonance imaging.

A

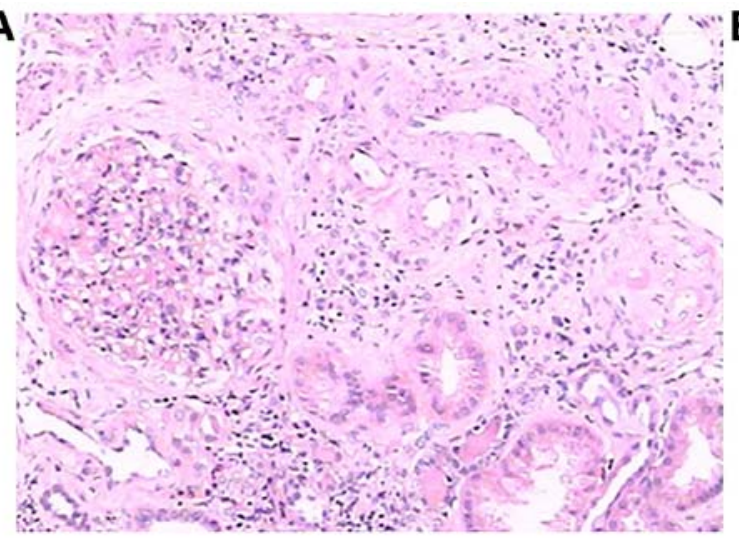

B

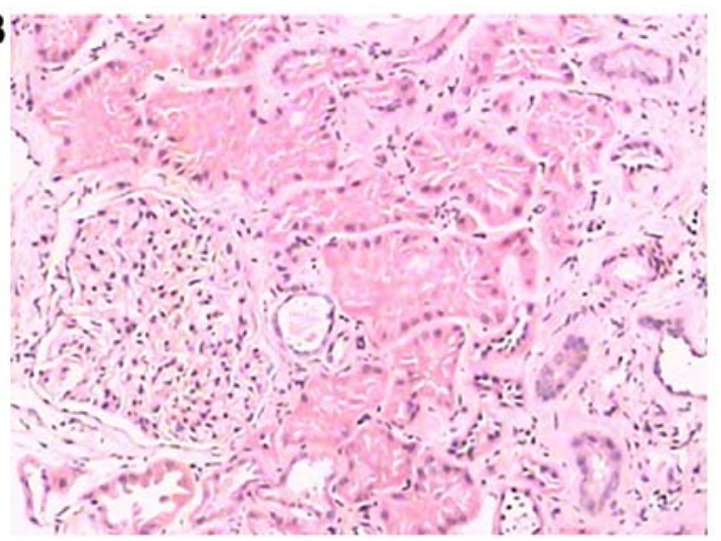

Figure 3. HE staining of the kidney tissues in P17 and P18. (A) HE staining field of kidney tissues in P17; enlarged glomeruli, accumulation of mesangial matrix, focal segmental glomerulus sclerosis, tubular epithelial cell necrosis, protein cast and inflammatory cell infiltrations were found. (B) HE staining field of kidney tissues in P18; accumulation of mesangial matrix, focal segmental glomerulus sclerosis, enlarged tubular, massive inflammatory cells infiltration and proliferation of fibrous tissue were found. Magnification, x200. HE, hematoxylin-eosin.

\section{Genetic investigations}

NPHS2 analysis. Sequencing of NPHS2 revealed two heterozygous variants. $102 \mathrm{~A}>\mathrm{G}$ was detected in exon 1 of all nine members, with no differences in the 34-glycine podocin protein. Another variant, $954 \mathrm{C}>\mathrm{T}$, was discovered in exon
8 of the two index patients and four other family members, including P4, P5, P19 and P20, suggesting that this variant was inherited from the mother $\mathrm{P} 4$ and passed on to her three children. P5 and his son P20 also carried this variation (Fig. 6A). 

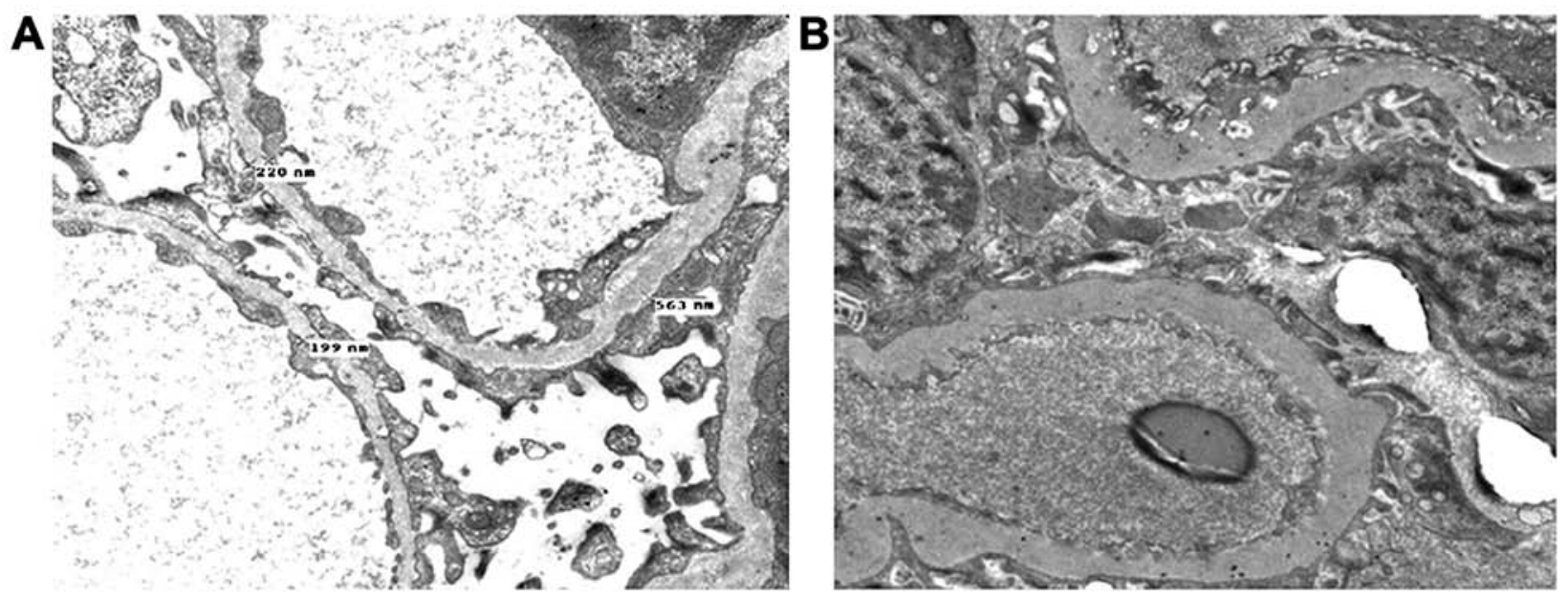

Figure 4. Electron microscopy of the kidney tissues in P17 and P18. (A) Electron microscopy of the kidney tissues in P17: Expansion of the glomerular basement membrane, mesangial cells and matrix, extensive fusion of the epithelial foot process and enlarged tubules. (B) Electron microscopy of the kidney tissues in P18: Enlarged capillaries and basement membrane, extensive fusion of the epithelial foot process, dilatation of the tubules and inflammatory cell infiltration in the interstitium. Magnification, x13,500.
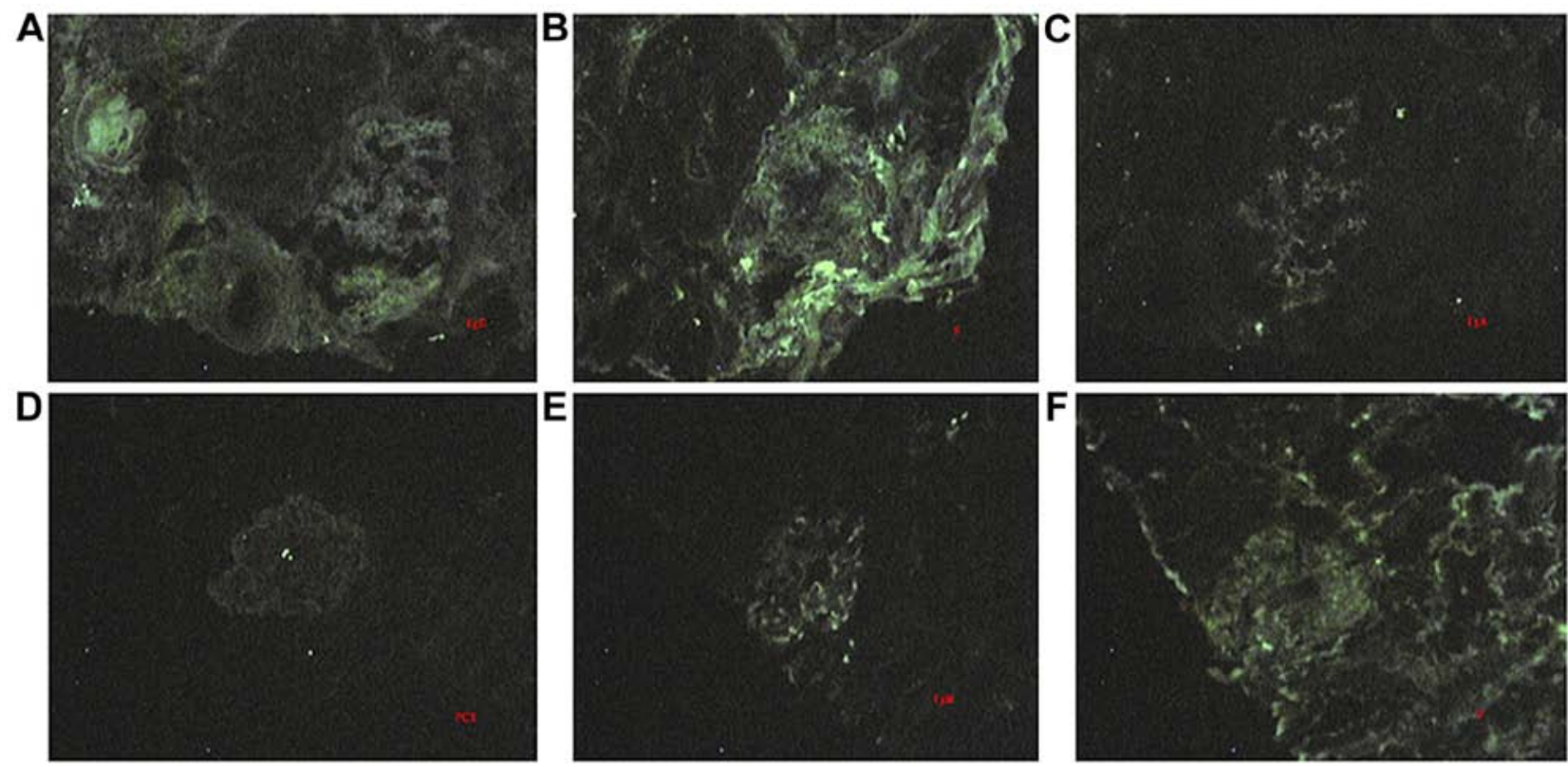

Figure 5. Immunofluorescence staining of the kidney tissues in P17 and P18. (A) High deposition of IgG in the mesangial area. (B) Fib was deposited in the mesangial area as a mass. (C) IgA was deposited in the mesangial area as a mass. (D) No significant deposition of PCX. (E) High deposition of IgM in the mesangial zone. (F) High deposition of Fib in the mesangial zone. Magnification, x400. PCX, podocalyxin; Fib, fabrillarin.

WT1 analysis. Two novel variations were found through WT1 sequencing, including 330C $>$ T and 1107A $>$ G. 330C $>$ T was detected in exon 1 in P17, P18, P1, P4, P5, P19 and P22. This variation was inherited from their grandfather P1 and was passed on to his son P5; P4 and P22, as mother and sister of $\mathrm{P} 17$ and $\mathrm{P} 18$, also carried the variation. 1107A $>\mathrm{G}$ was present in exon 7 in $\mathrm{P} 17, \mathrm{P} 18, \mathrm{P} 1, \mathrm{P} 4$ and $\mathrm{P} 9$, suggesting that $\mathrm{P} 9$ inherited this variation from his father, $\mathrm{P} 1$. P4 also carried the variation and passed it on to her three children P17, P18 and P20 (Fig. 6B).

ACTN4 analysis. In ACTN4 sequencing, two variations considered as gene polymorphisms were identified. $537 \mathrm{G}>\mathrm{A}$ and $2563 \mathrm{~T}>\mathrm{C}$ variants were only detected in exon 5 and exon
20 in two patients, P17 and P18. No mutations of this gene were found in other family members (Fig. 6C).

PLCE1 analysis. Five heterozygous variants in PLCE1 were found. $810 \mathrm{~T}>\mathrm{C}$ and $960 \mathrm{G}>\mathrm{A}$ in exon 1 were detected in P17, P4 and P22. In exon 23 and 25 of P17, P4, P21 and $\mathrm{P} 22$, variants including $5330 \mathrm{C}>\mathrm{T}$ and $5780 \mathrm{~A}>\mathrm{G}$ were found. Furthermore, $4724 \mathrm{G}>\mathrm{C}$ in exon 19 was identified in P17, P18, P4 and P19 (Fig. 6D). Of these affected members, P17, P18 and P19 were siblings and the children of P3 and P4, and P22 is the son of $\mathrm{P} 7$ and $\mathrm{P} 8$.

UMOD analysis. Variants of $264 \mathrm{C}>\mathrm{T}$ in exon 4 were confirmed in index patient P17. Variants in UMOD also occurred in four 


\section{A NPHS2}

GCAAAGGCCGAGAGGAGCGGCGGAGGCCGCGGGCGCCAGGAGGCT

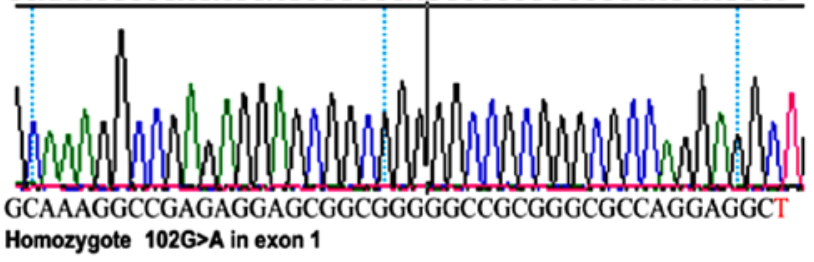

ATTCTGTCAGGCACCCCTGCTGCCGTTCAGCTTCGATACCTCCACAC

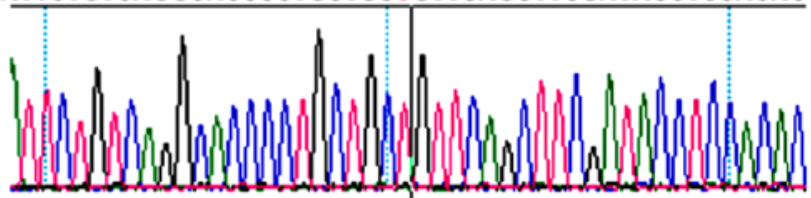

ATTCTGTCAGGCACCCCTGCTGCTGTTCAGCTTCGATACCTCCACAC Homozygote 954T>C in exon 8

\section{B WT1}

TGGGCGCCGGTGCTGGACTTTGCGCCCCCGGGCGCTTCGGCTTACG

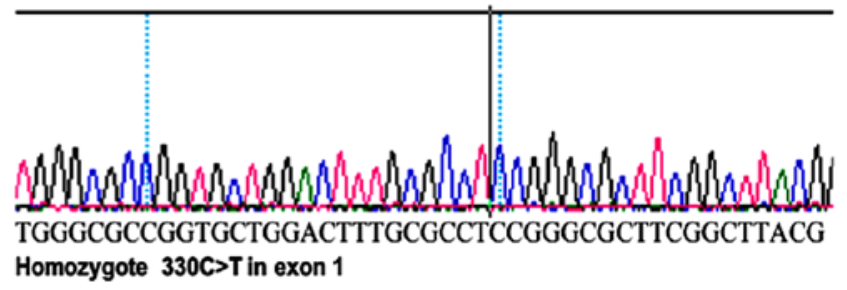

GATGTGCGACGTGTGCCTGGAGTAGCCCCGACTCT

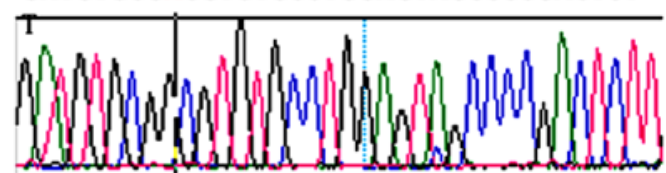

GATGTGCGGCGTGTGCCTGGAGTAGCCCCGACTCT

Homozygote 1107A>G in exon 7

\section{ACTN4}

GTGCCAGAGAAAGACAGCCCGTATAAGAACGTCAATGTGCAGAAC

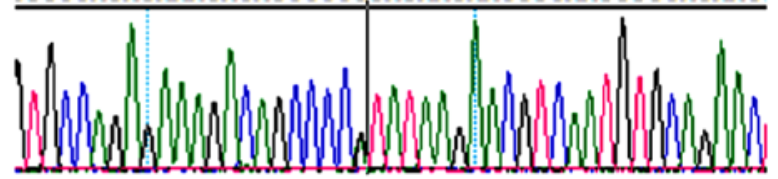

GTGCCAGAGAAAGACAGCCCATATAAGAACGTCAATGTGCAGAAC Homozygote 537G>A in exon 5

GGTCATCGCTTCCTTCAAGGTCTTAGCAGGGGACAAGGTGAGCGAGA

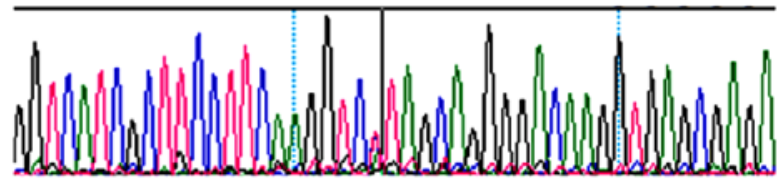

GGTCATCGCTTCCTTCAAGGTCCTAGCAGGGGACAAGGTGAGCGAGA Homozygote 2563T>C in exon 20

\section{PLCE1}

ATACTTTTGCTTTGAAGGCTCTTGTGAGAAGGTTGACATGGTATA

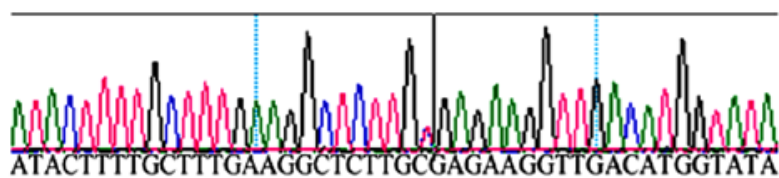

Homozygote $810 T>C$ in exon 1

CGGTGGGAATGCCAACCCCGACCTGCCAATAATGAGGAAGAGG

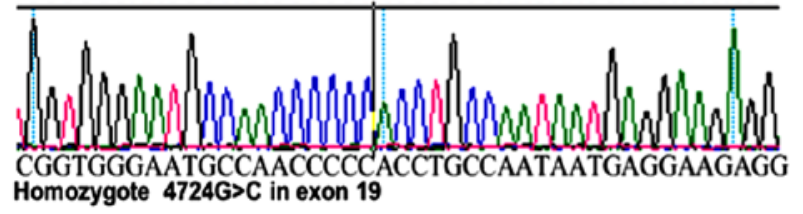

GAACGAGCAGTTTCTGTTCCACGTTCACTTCGAAGATCTTGTATTT

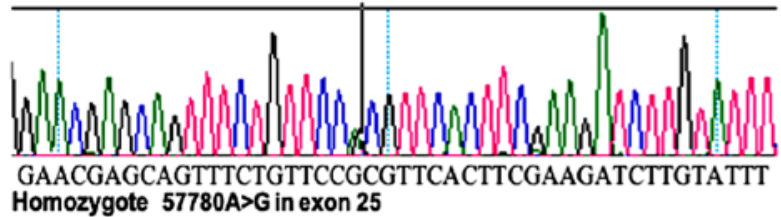

Homozygote $57780 \mathrm{~A}>\mathrm{G}$ in exon 25

ACGCTTTTAAAAGCAAAAAGGAGCGATCCACTTTGTTAGTCAGGAGATTC

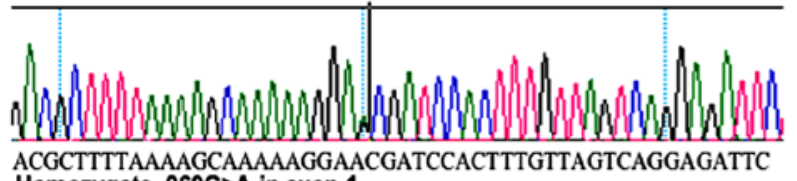

ACGCTTTTAAAAGCAAAAAGGAACG
Homozygote $960 \mathrm{G}>\mathrm{A}$ in exon 1

TCGCAGGTATTCTCAGAAACTGACCCAGCACACCGCCTGTCAGCTG

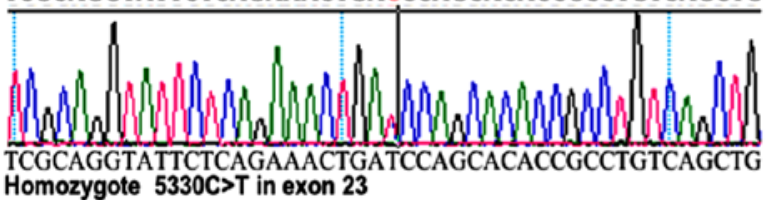

\section{E UMOD}

CTGCGTAAACACGCCAGGCTCCTTCTCCTGCGTCTG

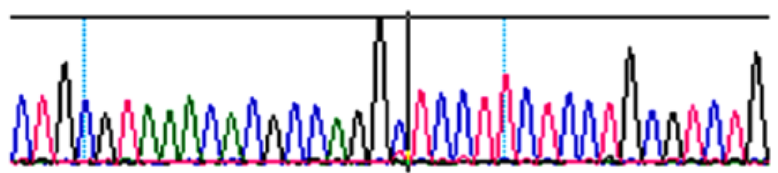

CTGCGTAAACACGCCAGGTTCCTTCTCCTGCGTCTG Homozygote 264C>T in exon 4

F ACE

T C C C GA G T T C T G G G A A G G T C G

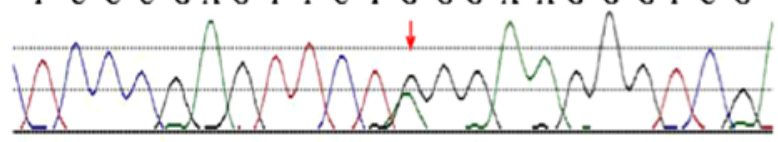

Homozygote 1028G>A in exon 7

Figure 6. Variants of NPHS2, WT1, ACTN4, PLCE1, UMOD and ACE identified by gene sequencing. Variants of 6 high prevalent genes in 10 family members were identified. (A) Two nonsense mutation of NPHS2, including 102A $>\mathrm{G}$ and $954 \mathrm{C}>\mathrm{T}$. (B) Two novel variants of WT1, including 330C $>\mathrm{T}$ and $1107 \mathrm{~A}>\mathrm{G}$. (C) Two heterozygous variants of $537 \mathrm{G}>\mathrm{A}$ and $2563 \mathrm{~T}>\mathrm{C}$ in ACTN4. (D) Five heterozygous variants of $P L C E 1$ including $810 \mathrm{~T}>\mathrm{C}, 960 \mathrm{G}>\mathrm{A}, 5330 \mathrm{C}>\mathrm{T}$, $5780 \mathrm{~A}>\mathrm{G}$, and $4724 \mathrm{G}>\mathrm{C}$. (E) Nonsense mutation $264 \mathrm{C}>\mathrm{T}$ in $U M O D$. (F) Causative nonsense mutation 1028G $>\mathrm{A}$ in ACE. WT1, wilms tumor 1; ACTN4, actinin $\alpha$ 4; NPHS2, nephrosis 2; PLCE1, phospholipase C $\varepsilon 1 ; A C E$, angiotensin I converting enzyme; UMOD, uromodulin.

healthy family members, including first generation P1, his daughter P9 who belonged to the second generation, as well as P21 and P22 who belonged to the third generation (Fig. 6E). The deposition of $U M O D$ was further confirmed with immunohistochemistry detection. Uneven $U M O D$ depositions were found in the renal tubular epithelial cells of the two index patients (Fig. 7). 

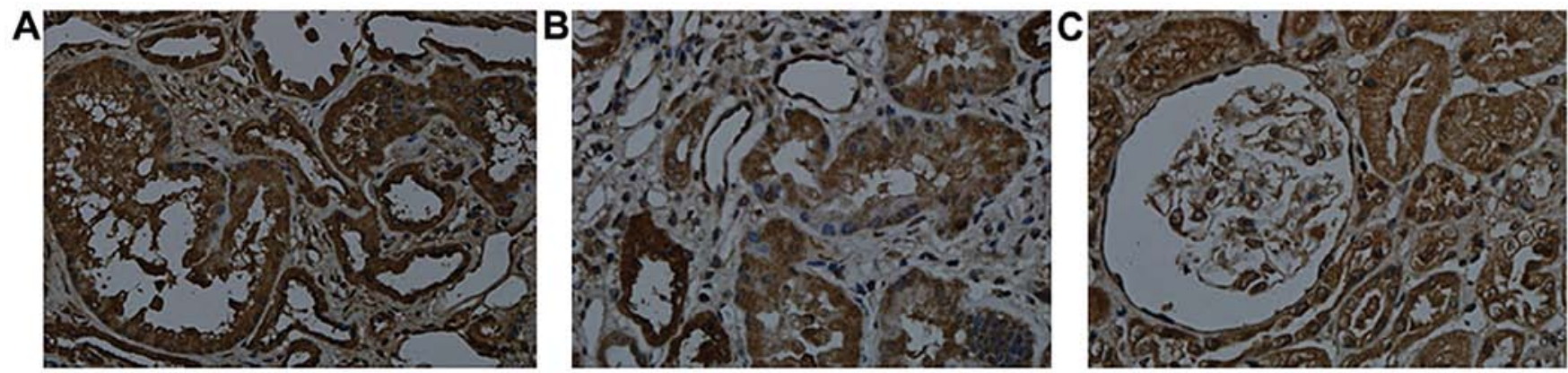

Figure 7. Immunohistochemical staining of UMOD in the kidney tissues. (A) UMOD immunohistochemical staining in the kidney tissues of P17. UMOD depositions were observed in the renal tubular epithelial cells. (B) UMOD immunohistochemical staining of the kidney tissues in P18. UMOD depositions were observed in the renal tubular epithelial cells. (C) UMOD immunohistochemical staining in the kidney tissues of P20. No UMOD depositions were observed in the renal tubular epithelial cells. Magnification, x400. UMOD, uromodulin.

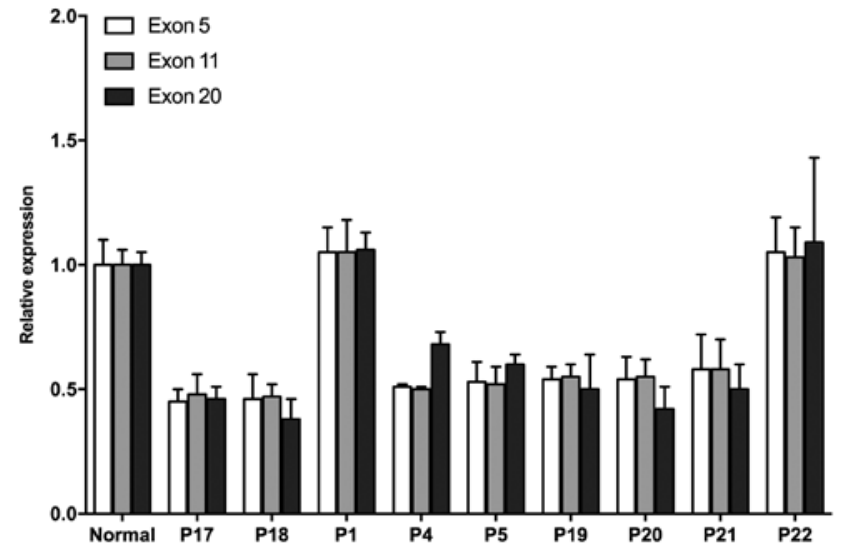

Figure 8. Homozygous deletion mutation of NPHP1. Expression of NPHP1 was measured using reverse transcription-quantitative PCR and normalized with healthy control (Normal). No expression of NPHP1 was observed in P17. NPHP1, nephrocystin 1.

ACE analysis. A causative variant $1028 \mathrm{G}>\mathrm{A}$ was identified in $A C E$ in the index patients $\mathrm{P} 17$ and $\mathrm{P} 18$ and presented with no variants in the other family members (Fig. 6F).

NPHP1 analysis. Homozygous deletion mutation of NPHPI was found in exon 5, 11 and 20 in both P17 and P18. Their sister P19, as well as cousins P20 and P21 who belonged to the third generation, also experienced loss of heterozygosity (LOH) in NPHP1. LOH was also confirmed in two of the second-generation members: $\mathrm{P} 4$, the mother of the two index patients, and P5, the father of P20 and P21 (Fig. 8).

In silico analysis. Homozygous deletions in NPHP1 and heterozygous deletion in $A C E$ were found in the following mutation identification analysis. Homozygous deletion mutation of $N P H P I$ in exons 5, 11 and 20 could be passed down to the next generation via $\mathrm{X}$-linked recessive inheritance. In contrast, a variant in $A C E$ was shown to be a disease-causing mutation that was predicted to alter 343-bit amino acid from Trp to a stop codon. Mutations in both NPHPI and ACE can lead to a frame shift and a truncated protein, thus stopping the production of the target protein and leading to a loss of function, resulting in disease. In addition, no pathogenic variants were found in other genes of the panel with sequencing, indicating that these missense variations are gene polymorphisms that don't cause disease.

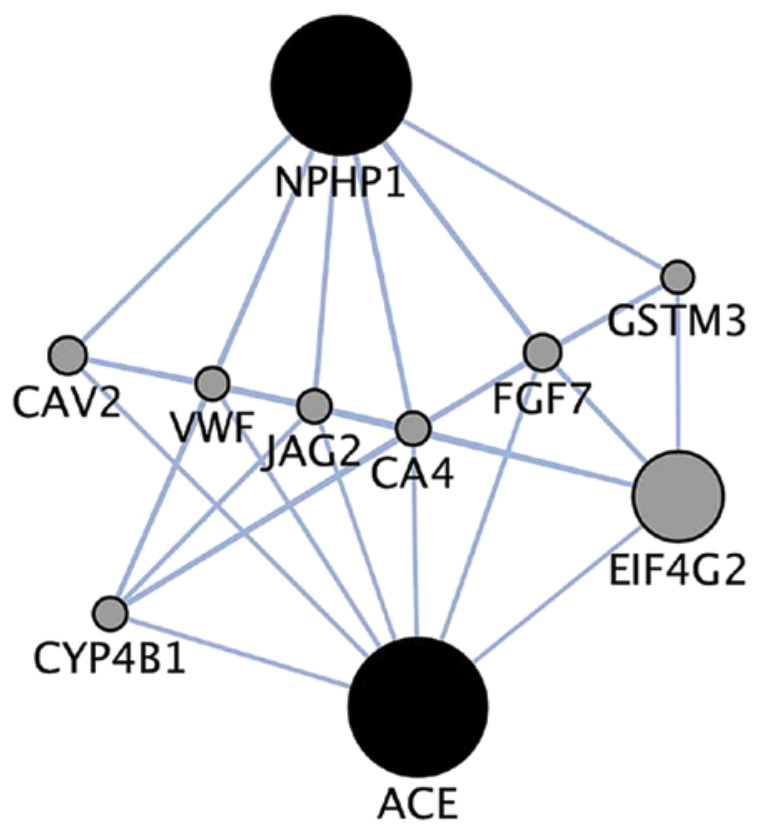

Figure 9. Co-location network generated via GeneMANIA analysis. Co-location network of NPHP1 and ACE. Black dots represent NPHP1 and ACE; gray dots are directly related co-location gene. NPHP1, nephrocystin 1; ACE, angiotensin I converting enzyme.

Additionally, co-location analysis of the genes, using GeneMANIA, showed direct and indirect co-locations for NPHPI and $A C E$. Caveolin 2, von Willebrand factor, jagged canonical notch ligand 2 , carbonic anhydrase 4 and fibroblast growth factor 7 are direct co-location genes, while the other genes can influence these six direct genes and further activate NPHPl or ACE (Fig. 9).

\section{Discussion}

In the present study, cases in a family with heredity nephropathy with heterozygous genetic variants in NPHS2, WT1, ACTN4, PLCE1, ACE, UMOD and NPHP1 deletion were presented. A renal biopsy of two index patients showed sclerosing glomerulonephritis, dilated tubules and lymphocyte/monocyte infiltration in the interstitium. Combined with the results of routine serum/urine tests and family history investigation, hereditary tubular disease was suggested. Disease-causing mutations included homozygous deletions in NPHPI; therefore, familial adolescent NPH was 
diagnosed for the two index patients. Network analysis discovered direct and indirect co-location genes of NPHPI and ACE.

FSGS is characterized as a morphological/histological injury rather than a specific glomerular disease (23). Even though sclerosing nephritis and focal segmental glomerulosclerosis were found in the index patients, significant dilated renal tubules and high infiltration in the interstitium also showed a high possibility of hereditary tubular disease. Considering the three main pathological changes of NPH, including renal tubular basement membrane destruction, tubular atrophy and cystic changes, it was hypothesized that glomerular injury, secondary to the tubular and interstitial damages, may have occurred in the patients (6).

Further SNP screening analysis indicated no causative mutations in common FSGS-related genes, including NPHS2, WT1, ACTN4 and PLCE1; this further lowered the probability of FSGS. Homozygous deletion of NPHPI is reported to be the most common mutation in NPH $(24,25)$. NPHPl deficiency occurs in Iranian, Turkish, Japanese and French families with $\mathrm{NPH}$, indicating a strong possibility of NPH diagnosis in this Chinese nephrotic family (26-28). This study showed that NPHPl was vertically transmitted between the second and third generation, indicating the possibility of familial adolescent NPH diagnosis. Notably, the mother of the index patients carried a LOH of NPHPl, her two sons showed homozygous deletion in NPHP1 and her daughter had LOH of NPHPl, indicating that mutations or mutant isomers carried by their mother were very likely to be inherited by her children (29).

NPH is an inherited renal disease associated with tubule-interstitial damage that causes end-stage renal disease (30). Depending on the age at onset, it is categorized as infantile, juvenile and adolescent NPH; adolescent NPH is the most common form (31). Adolescent-onset NPH patients present with polyuria and polydipsia symptoms at $\sim 4-6$ years of age, and end-stage renal disease (ESRD) developed at an average age of 19 years (32). The index patients progressed to ESRD at the age of 20 and 16 years, consistent with adolescent NPH. In addition, the patients showed an extremely high degree of hyperuricemia, when compared to the reference ranges. Unlike primary hyperuricemia, hyperuricemia in NPH-medullary cystic kidney disease (MCKD) is caused by decreased tubular uric acid excretion (33). High uric acid retention that was detected in the two index patients was further evidence for the diagnosis of adolescent NPH.

A heterozygous pathological mutation in $A C E$ was also found in this study. Research has suggested that $A C E$-deficient mice can develop symptoms characteristic of $N P H P$ pathology, including decreased urine concentration, hypotension and progressive renal failure $(34,35)$. However, the possibility of these two genes as pathogenic genes was excluded from the genetic screening of three Italian families with confirmed nephropathy (36). Patients with NPH can show a variety of different phenotypes, such as Oculomotor apraxia type Cogan, liver fibrosis, MCKD and Joubert/Meckel-Gruber syndromes, and other multi-system injuries (15). Considering the co-location genes between NPHPI and $A C E$, it was hypothesized that $A C E$ could be involved, however further validation is needed $(32,37,38)$.

The present study has certain limitations. Firstly, this was single-center research, therefore the generalizability of these results for all adolescent patients with NPH with hereditary nephropathy is limited. Multi-center research is needed to confirm our results. Secondly, samples were limited; only a single large family with nephropathy history was studied. Although a total of seven family branches were included, patients from different families should be enrolled and investigated in the future. Thirdly, the lack of in vitro experiments to validate the present results was also a limitation of this study. Additional in vitro experiments are needed to verify the possible pathogenic factors. In spite of these limitations, these results provide information regarding the prevalence of familial adolescent NPH in China and suggest that NPH should be considered as a common cause of hereditary nephropathy.

In conclusion, familial adolescent NPH was diagnosed in two index patients in this study. Therefore, it is recommended that comprehensive gene mutation screening combined with kidney biopsy detection is used for the diagnosis of hereditary nephrotic disease, and concern should be raised about gene variants related to multiple organ system comorbidities.

\section{Acknowledgements}

Not applicable.

\section{Funding}

The present study was supported by Guangdong Provincial Science and Technology Project Fund for Key Scientific Research Base for Metabolic Disease Related Clinical Nutrition (grant no. 2014B030303002) and Guangdong Provincial Academician workstation Fund (grant no. 2017B09090 4027).

\section{Availability of data and materials}

All data generated or analyzed during the present study are included in this published article.

\section{Authors' contributions}

CT and DZ contributed to analyzing data and drafting the manuscript; RT and XZ contributed to the interpretation of data and manuscript revision; XX, DQ, YuL and JH collected and analyzed the data; YaL contributed to the conception and design of the present study. All authors read and approved the final manuscript.

\section{Ethics approval and consent to participate}

The present study was approved by The Ethics Committee of the Guangzhou Red Cross Hospital (permit no. 20121228) and adhered to the tenets of the Declaration of Helsinki and the Guidance on Sample Collection of Human Genetic Diseases given by the Ministry of Public Health of China. Consent forms were signed by patients or their guardians.

\section{Patient consent for publication}

This study has followed the principles of anonymity; no direct or indirect identifiers of our participants were used for publication.

\section{Competing interests}

The authors declare that they have no competing interests. 


\section{References}

1. Tianjun G, Zhihong L, Zhaohong C, Wweixin H, XIiaodan Y and Zheng T: Association studies of gene polymorphism in lupus nephritis. Chin J Nephrol Dial Transplant: 5-10, 100, 1997.

2. Sharif B and Barua M: Advances in molecular diagnosis and therapeutics in nephrotic syndrome and focal and segmental glomerulosclerosis. Curr Opin Nephrol Hypertens 27: 194-200, 2018.

3. Hou JH, Zhu HX, Zhou ML, Le WB, Zeng CH, Liang SS, Xu F, Liang DD, Shao SJ, Liu Y and Liu ZH: Changes in the spectrum of kidney diseases: An analysis of 40,759 biopsy-proven cases from 2003 to 2014 in China. Kidney Dis (Basel) 4: 10-19, 2018.

4. Sperry ZJ, Na K, Parizi SS, Chiel HJ, Seymour J, Yoon E and Bruns TM: Flexible microelectrode array for interfacing with the surface of neural ganglia. J Neural Eng 15: 036027, 2018.

5. Rosenberg AZ and Kopp JB: Focal segmental glomerulosclerosis. Clin J Am Soc Nephrol 12: 502-517, 2017.

6. Wolf MTF and Hildebrandt F: Nephronophthisis. Pediatr Nephrol 26: 181-194, 2011.

7. Choi M, Scholl UI, Ji W, Liu T, Tikhonova IR, Zumbo P, Nayir A, Bakkaloğlu A, Ozen S, Sanjad S, et al: Genetic diagnosis by whole exome capture and massively parallel DNA sequencing. Proc Natl Acad Sci USA 106: 19096-19101, 2009.

8. McInerney-Leo AM, Marshall MS, Gardiner B, Benn DE, McFarlane J, Robinson BG, Brown MA, Leo PJ, Clifton-Bligh RJ and Duncan EL: Whole exome sequencing is an efficient and sensitive method for detection of germline mutations in patients with phaeochromcytomas and paragangliomas. Clin Endocrinol (Oxf) 80: 25-33, 2014

9. Clifford RJ, Edmonson MN, Nguyen C, Scherpbier T, Hu Y and Buetow KH: Bioinformatics tools for single nucleotide polymorphism discovery and analysis. Ann N Y Acad Sci 1020: 101-109, 2004.

10. Benetti E, Caridi G, Malaventura C, Dagnino M, Leonardi E, Artifoni L, Ghiggeri GM, Tosatto SC and Murer L: A novel WT1 gene mutation in a three-generation family with progressive isolated focal segmental glomerulosclerosis. Clin J Am Soc Nephrol 5: 698-702, 2010.

11. Dhandapani MC, Venkatesan V, Rengaswamy NB, Gowrishankar K, Nageswaran P and Perumal V: Association of ACE and MDR1 gene polymorphisms with steroid resistance in children with idiopathic nephrotic syndrome. Genet Test Mol Biomarkers 19: 454-456, 2015.

12. Sako M, Nakanishi K, Obana M, Yata N, Hoshii S, Takahashi S, Wada N, Takahashi Y, Kaku Y, Satomura K, et al: Analysis of NPHS1, NPHS2, ACTN4, and WT1 in Japanese patients with congenital nephrotic syndrome. Kidney Int 67: 1248-1255, 2005.

13. Halbritter J, Porath JD, Diaz KA, Braun DA, Kohl S, Chaki M, Allen SJ, Soliman NA, Hildebrandt F and Otto EA; GPN Study Group: Identification of 99 novel mutations in a worldwide cohort of 1,056 patients with a nephronophthisis-related ciliopathy. Hum Genet 132: 865-884, 2013.

14. Kang HG, Lee HK, Ahn YH, Joung JG, Nam J, Kim NK, Ko JM, Cho MH, Shin JI, Kim J, et al: Targeted exome sequencing resolves allelic and the genetic heterogeneity in the genetic diagnosis of nephronophthisis-related ciliopathy. Exp Mol Med 48: e251, 2016.

15. Wolf MTF, Lee J,Panther F, Otto EA, Guan KL and Hildebrandt F: Expression and phenotype analysis of the nephrocystin-1 and nephrocystin-4 homologs in Caenorhabditis elegans. J Am Soc Nephrol 16: 676-687, 2005.

16. Waldherr R, Lennert T, Weber HP, Födisch HJ and Schärer K: The nephronophthisis complex-A clinicopathologic study in children. Virchows Arch A Pathol Anat Histol 394: 235-254, 1982.

17. Chaki M, Hoefele J, Allen SJ, Ramaswami G, Janssen S, Bergmann C, Heckenlively JR, Otto EA and Hildebrandt F: Genotype-phenotype correlation in 440 patients with NPHP-related ciliopathies. Kidney Int 80: 1239-1245, 2011.

18. Wolf MTF, Mucha BE, Attanasio M, Zalewski I, Karle SM, Neumann HP, Rahman N, Bader B, Baldamus CA, Otto E, et al: Mutations of the Uromodulin gene in MCKD type 2 patients cluster in exon 4, which encodes three EGF-like domains. Kidney Int 64: 1580-1587, 2003.

19. Rinschen MM, Schermer B and Benzing T: Vasopressin-2 receptor signaling and autosomal dominant polycystic kidney disease: From bench to bedside and back again. J Am Soc Nephrol 25: 1140-1147, 2014

20. Livak KJ and Schmittgen TD: Analysis of relative gene expression data using real-time quantitative PCR and the 2(-Delta Delta C(T)) method. Methods 25: 402-408, 2001.
21. Richards S, Aziz N, Bale S, Bick D, Das S, Gastier-Foster J, Grody WW, Hegde M, Lyon E, Spector E, et al: Standards and guidelines for the interpretation of sequence variants: A joint consensus recommendation of the American college of medical genetics and genomics and the association for molecular pathology. Genet Med 17: 405-424, 2015.

22. Montojo J, Zuberi K, Rodriguez H, Kazi F, Wright G, Donaldson SL, Morris Q and Bader GD: GeneMANIA cytoscape plugin: Fast gene function predictions on the desktop. Bioinformatics 26: 2927-2928, 2010

23. Angioi A and Pani A: FSGS: From pathogenesis to the histological lesion. J Nephrol 29: 517-523, 2016.

24. Soliman NA, Hildebrandt F, Allen SJ, Otto EA, Nabhan MM and Badr AM: Homozygous NPHP1 deletions in Egyptian children with nephronophthisis including an infantile onset patient. Pediatr Nephrol 25: 2193-2194, 2010.

25. Yang X, Kanegane H, Nishida N, Imamura T, Hamamoto $K$, Miyashita R, Imai K, Nonoyama S, Sanayama K, Yamaide A, et al: Clinical and genetic characteristics of XIAP deficiency in Japan. J Clin Immunol 32: 411-420, 2012.

26. Gheissari A, Harandavar M, Hildebrandt F, Braun DA, Sedghi M, Parsi N, Merrikhi A, Madihi Y and Aghamohammadi F: Gene mutation analysis in Iranian children with nephronophthisis: A two-center study. Iran J Kidney Dis 9: 119-125, 2015.

27. Hoefele J, Nayir A, Chaki M, Imm A, Allen SJ, Otto EA and Hildebrandt F: Pseudodominant inheritance of nephronophthisis caused by a homozygous NPHP1 deletion. Pediatr Nephrol 26: 967-971, 2011.

28. Saunier S, Calado J, Benessy F, Silbermann F, Heilig R, Weissenbach J and Antignac C: Characterization of the NPHP1 locus: Mutational mechanism involved in deletions in familial juvenile nephronophthisis. Am J Hum Genet 66: 778-789, 2000.

29. Caridi G, Dagnino M, Rossi A, Valente EM, Bertini E, Fazzi E, Emma F, Murer L, Verrina E and Ghiggeri GM: Nephronophthisis type 1 deletion syndrome with neurological symptoms: Prevalence and significance of the association. Kidney Int 70: 1342-1347, 2006.

30. Sugimoto K, Takemura Y, Yanagida H, Fujita S, Miyazawa T, Sakata N, Okada M and Takemura T: Renal tubular dysgenesis and tubulointerstitial nephritis antigen in juvenile nephronophthisis. Nephrology (Carlton) 16: 495-501, 2011.

31. Salomon R, Saunier S and Niaudet P: Nephronophthisis. Pediatr Nephrol 24: 2333-2344, 2009.

32. Hildebrandt F, Strahm B, Nothwang HG, Gretz N, Schnieders B, Singh-Sawhney I, Kutt R, Vollmer M and Brandis M; Members of the APN Study Group: Molecular genetic identification of families with juvenile nephronophthisis type 1: Rate of progression to renal failure. Kidney Int 51: 261-269, 1997.

33. Bleyer AJ, Woodard AS, Shihabi Z, Sandhu J, Zhu H, Satko SG, Weller N, Deterding E, McBride D, Gorry MC, et al: Clinical characterization of a family with a mutation in the uromodulin (Tamm-Horsfall glycoprotein) gene. Kidney Int 64: 36-42, 2003.

34. Krege JH, John SWM, Langenbach LL, Hodgin JB, Hagaman JR, Bachman ES, Jennette JC, O'Brien DA and Smithies O: Male-female differences in fertility and blood pressure in ACE-deficient mice. Nature 375: 146-148, 1995.

35. Esther CR Jr,Howard TE, Marino EM, Goddard JM,Capecchi MR and Bernstein KE: Mice lacking angiotensin-converting enzyme have low blood pressure, renal pathology, and reduced male fertility. Lab Investig 74: 953-965, 1996.

36. Omran H, Häffner K, Vollmer M, Pigulla J, Wagner G, Caridi G and Hildebrandt F: Exclusion of the candidate genes ACE and Bcl-2 for six families with nephronophthisis not linked to the NPH1 locus. Nephrol Dial Transplant 14: 2328-2331, 1999.

37. Sang L, Miller JJ, Corbit KC, Giles RH, Brauer MJ, Otto EA, Baye LM, Wen X, Scales SJ, Kwong M, et al: Mapping the NPHP-JBTS-MKS protein network reveals ciliopathy disease genes and pathways. Cell 145: 513-528, 2011.

38. Tory $\mathrm{K}$, Lacoste $\mathrm{T}$, Burglen L, Morinière $\mathrm{V}$, Boddaert $\mathrm{N}$, Macher MA, Llanas B, Nivet H, Bensman A, Niaudet P, et al: High NPHP1 and NPHP6 mutation rate in patients with Joubert syndrome and nephronophthisis: Potential epistatic effect of NPHP6 and AHI1 mutations in patients with NPHP1 mutations. J Am Soc Nephrol 18: 1566-1575, 2007.

This work is licensed under a Creative Commons Attribution-NonCommercial-NoDerivatives 4.0 International (CC BY-NC-ND 4.0) License. 